Fikrah: Jurnal Ilmu Aqidah dan Studi Keagamaan

issn 2354-6147 eissn 2476-9649

Tersedia online di: journal.stainkudus.ac.id/index.php/Fikrah

DOI: https://doi.org/10.21043/fikrah.v4i1.1638

Artikel diserahkan : 26 Agustus 2016; Diterima: 5 Oktober 2016

\title{
Pendidikan Islam, Pendidikan Politik, Dan Dialog Antar Umat Beragama Di Indonesia
}

\author{
Ulfa Masamah \\ STAIN Kudus, Indonesia \\ ulfamasamah@yahoo.com \\ Mualimul Huda \\ STAIN Kudus \\ hudamahbubi@gmail.com
}

\begin{abstract}
Abstrak
Pendidikan Islam menghasilkan kemampuan intelektual muslim yang memadai sehingga melahirkan budaya politik yang humanistictheosentris, humanistic-patriotik, dan apabila gagal memupuk intelektualitas akan melahirkan budaya politik yang hedonisticegoistik. Perbaikan pendidikan agama mono-religius bertujuan mengkristalkan pengalamannya menjadi suatu sikap terbuka yang berperan penting menyiapkan generasi masa depan dan tatanan masyarakat dialogis. Pendidikan politik diorientasikan menanamkan nilai-nilai demokratis seperti keterbukaan, perasaan saling menghargai, simpati, empati, solidaritas, dan adanya pemahaman pluralisme dalam kehidupan masyarakat Indonesia yang majemuk. Perlunya konsep moderasi yang menghindari sikap ekstrim dalam dua sisinya, guna menciptakan ummatan wasathan. Tatanan kehidupan keberagamaan harmonis berdasarkan nilai-nilai agama akan terwujud melalui dialog umat beragama. Dialog antar umat beragama sebagai wahana menemukan gagasan progresif dan menghindari cara-cara manipulatif serta agresifitas umat beragama. Rutinitas dialog yang dilakukan oleh lembaga pemerintah, lembaga sosial kemasyarakatan, dan pemuka agama harus selalu ditingkatkan. Hasil dialog tersebut akan diaplikasikan dalam kehidupan beragama, berbangsa, dan bernegara di Indonesia.
\end{abstract}

Kata kunci: Demokrasi, dialog antar umat beragama, humanisme, pendidikan islam, pendidikan politik. 


\begin{abstract}
Islamic education produces the prominent intellectual Muslim bringing to the political culture of humanistic-theocentric, humanistic-patriotic. If they fail to cultivate the intellect, it will cause a political culture of hedonistic-egoistic. The religious education aims at crystallizing the mono-religious experience of being an open attitude that is important to prepare future generations and a society dialogue. Political education is oriented to instill democratic values such as openness, mutual respect, sympathy, empathy, solidarity, and their understanding of pluralism in Indonesia. The need of the moderation concept which avoids extremes has goals to create al-ummatan wasathan. The harmonious religious life based on religious values will be realized by dialogue faiths. Inter-religious dialogue as a way to find the progressive idea and avoid manipulative ways and aggressiveness of religious communities. Routines dialogue conducted by government agencies, social institutions, and religious leaders must be improved. The results of this dialogue will be applied in religious life, nation, and state in Indonesia.
\end{abstract}

Keywords: Democracy, dialogue among religions, humanism, islamic education, political education.

\title{
Pendahuluan
}

Pendidikan Islam menghasilkan kemampuan intelektual muslim yang memadai sehingga melahirkan budaya politik yang humanistic-theosentris, humanisticpatriotik, dan apabila gagal memupuk intelektualitas akan melahirkan budaya politik yang hedonistic-egoistik. Melihat kondisi politik dewasa ini, rekonstruksi pendidikan politik untuk memperteguh dimensi kontrak sosial-keagamaan dalam pendidikan Islam sudah sangat mendesak untuk diadakan. Perbaikan pendidikan agama mono-religius bertujuan mengkristalkan pengalamannya menjadi suatu sikap terbuka yang berperan penting menyiapkan generasi untuk masa depan tatanan masyarakat dialogis. Pendidikan politik mensyaratkan adanya ruang demokratisasi sebagai sarana untuk membangun masyarakat yang dialogis dengan orientasi perubahan perilaku serta sikap, kualitas dan berbagai aspek. Pendidikan politik diorientasikan menanamkan nilai-nilai demokratis seperti keterbukaan, perasaan saling menghargai, simpati, empati, solidaritas, dan adanya pemahaman pluralisme dalam kehidupan masyarakat Indonesia yang majemuk. Perlunya konsep moderasi yang menghindari sikap ekstrim dalam dua sisinya, guna menciptakan ummatan wasathan. Tatanan kehidupan keberagamaan harmonis berdasarkan nilai-nilai agama akan terwujud melalui dialog umat beragama.

Manusia mempunyai fitrah sebagai makhluk politik yang tidak dapat dipisahkan dengan konteks sosialnya. Perbedaan yang ada dalam bentuk fisiologis manusia sebenarnya merupakan sunatullah yang seharusnya dihadirkan sebagai 
potensi untuk menciptakan kehidupan sosial yang menjunjung tinggi nilai-nilai toleransi. Keragaman suku bangsa, ras, etnik, bahasa, budaya maupun dialek selayaknya dijadikan potensi dasar untuk membangun kehidupan bersama yang damai serta meneguhkan pola interaksi sosial dalam mewujudkan kehidupan bersama yang tentram. Bukan malah sebaliknya, perbedaan yang ada di tengah kehidupan sosial yang kompleks dijadikan sebagai media disfungsional yang menyebabkan ketidakharmonisan sosial dan mengarah pada integrasi, konflik horisontal dan kekerasan sosial (Parekh, 1997, hal. 8).

Kehidupan sosial yang penuh dengan keragaman menjadi tantangan tersendiri dalammengusungnilaipolitikyangharmoni.Islamsebagaiagamadiyakinimempunyai nilai-nilai universal (rahmat lialamin) dengan serangkaian nilai-nilai kemanusiaan, kedamaian dan keharmonisan di tengah-tengah kehidupan sosial masyarakat. Islam dengan semangat religiusitasnya dituntut mampu untuk menumbuhkan kesadaran kepada masyarakat untuk hidup rukun dan berdampingan. Menggali kembali nilainilai universal (ta'shilu al-ushul) inilah yang harus dilakukan, bukan hanya sebatas persoalan partikular, sehingga Islam mempunyai cara pandang yang utuh dalam memotret kehidupan sosial politik masyarakat (Yaqin, 2005, hal. 45).

Implementasi Islam sebagai rahmat bagi kehidupan tanpa harus melihat latar belakang suku, ras, bahasa, gender dan geografis seseorang. Dalam pandangan ini Islam ditempatkan sebagai ruh (spirit) untuk membangun penghormatan terhadap hak asasi manusia (HAM). Menurut Wahid (1989, hal. 193-207), Islam harus dilihat dari fungsinya sebagai pandangan hidup yang mementingkan kesejahteraan warga masyarakat, apapun bentuk masyarakat yang digunakan, masyarakat Islam atau bukan.

Upaya membangun kerukunan umat beragama di tengah masyarakat yang heterogen, hendaknya dapat dilakukan dengan menumbuhkan semangat kebersamaan, pluralitas dan nasionalisme. Dalam semangat nasionalisme dapat diwujudkan dengan sikap dan rasa tanggungjawab sesuai dengan perannya dan mengesampingkan segala bentuk perbedaan dan keragaman yang ada. Dengan semangat nasionalisme (ar-ruh al-wathoniyyah) tercermin dari kemauannya untuk melestarikan budaya dan tradisi lokal dalam rangka menyelematkan identitas individu maupun masyarakat. Sedangkan dalam memupuk semangat pluralisme keberagamaan merupakan bentuk tantangan terbesar yang harus dihadapi oleh agama dewasa ini (Noer, 1998, hal. 128-135).

Islam sebagai agama menekankan perlunya sikap toleransi, kesamaan, kesederajatan, keadilan dan saling menghargai antar elemen bangsa yang beragam dalam proses berdemokrasi. Melalui pendidikan Islam sebagai agen perubahan sosial (agent social of change) diupayakan mampu menerjang problem yang bergerak dinamis dan proaktif untuk kemajuan dan perbaikan umat Islam. Pendidikan yang dipandang kurang humanis juga sering terjadi dalam proses pendidikan yang berdampak pada perkembangan peserta didik. Kaawoan (2014, hal. 70) menjelaskan bahwa pendidikan Islam untuk dijadikan wadah menyemai benih toleransi, 
harmoni kehidupan dan penghargaan yang tulus atas realitas keragaman kulturalreligius masyarakat. Sebab pendidikan Islam yang menjadi subsistem pendidikan nasional menjadi salah satu media yang paling efektif untuk melahirkan generasi yang memiliki pandangan yang mampu menjadikan keragaman sebagai bagian yang harus diapresiasi secara konstruktif. Dengan demikian tujuan pendidikan Islam yang telah dirumuskan harus diimplementasikan dalam kehidupan kebangsaan. Das sollen, tujuan pendidikan Islam sebagai proses pembentukan diri manusia agar sesuai dengan fitrah keberadaannya (Al-Attas, 1984, hal. 37). Di sinilah pendidikan merupakan usaha yang dilakukan oleh individu dan masyarakat untuk mentransmisikan nilai-nilai, kebiasaaan dan bentuk ideal mereka kepada generasi muda untuk membantu mereka meneruskan aktifitas kehidupan secara efektif (Sumartana et al., 2001, hal. 240).

Nuryatno (2011, hal. 415) menjelaskan bahwa pendidikan agama dalam konteks Indonesia yang pluralis, terutama pendidikan agama Islam masih ditemukan praktik dominan menggunakan model in the wall. Lebih lanjut, pendidikan agama Islam sudah saatnya digeser ke model at the wall, dan model beyond the wall. Agar siswa muslim memiliki pemahaman dan sikap terbuka dan proporsional dalam melihat perbedaan keyakinan. Dalam moment tertentu model at the wall, dan model beyond the wall ini menempatkan bahwa musuh bersama bukanlah perbedaan suku, agama, ras, gologan, dan etnis tetapi musuh bersama adalah kekerasan, penistaan, kemiskinan, ketidakadilan, korupsi dan sejenisnya. Di sisi lain, Noer (2001, hal. 233) menyatakan bahwa penekanan pendidikan agama (Islam) selama ini pada proses transfer ilmu agama kepada anak didik, bukan pada proses transformasi nilai-niai luhur keagamaan kepada anak didik untuk membimbing agar menjadi manusia yang berkepribadian kuat dan berakhlak mulia. Proses yang lebih banyak berlangsung dalam pendidikan agama selama ini adalah "pengajaran" agama, bukan "pendidikan" agama (Azra, 2012, hal. 5).

Hal senada juga diungkapkan secara jelas oleh Abdullah (2001, hal. 253) bahwa praktek di lapangan, memperlihatkan pendidikan dan pembelajaran agama pada umumnya, hingga saat ini masih lebih menekankan sisi keselamatan individu dan kelompoknya sendiri, dengan mengetepikan keselamatan yang dimiliki dan didambakan oleh orang lain di luar diri dan kelompoknya sendiri. Lebih lanjut, visi dan misi pendidikan agama tampak sekali diwarnai dan didominasi oleh asumsi dasar paradigma klasik skolastik dari para konseptor dan perancangnya yang terlalu menggarisbawahi keyakinan dan anggapan bahwa "keselamatan sosial" dan "keselamatan kelompok" amat ditentukan oleh dan tergantung pada "keselamatan individu”. Dengan kata lain, keselamatan individual jauh lebih pokok dan lebih utama dari pada keselamatan sosial. Sehingga dalam membangun perilaku toleran akan tetap memberikan penilaian, baik positif maupun negatif, terhadap pendapat orang lain dengan komitmen moral dan kesadaran menghormatinya. Berdasar pada fenomena tersebut, beberapa nilai mendasar yang harus menjadi fokus perhatian pendidikan politik Islam antara lain dengan penanaman kesadaran kepada masyarakat akan keragaman, kesetaraan, kemanusiaan, keadilan dan nilai-nilai 
demokrasi (Abdullah, 2005, hal. vxiii). Perlunya konsep moderasi yang menghindari sikap ekstrim atau berlebihan dalam dua sisinya, guna menciptakan masyarakat tengah dan adil (ummatan wasathan).

Di sini nilai-nilai demokratisasi akan melahirkan gagasan mengenai pendidikan politik yang dianggap mampu dijadikan solusi dalam mewujudkan pendidikan Islam yang humanis. Pendidikan yang tidak membenarkan adanya intimidasi, pengekangan dan pembatasan terhadap kreatifitas guru dan murid. Hal ini dapat diwujudkan dengan upaya menciptakan demokrasi pendidikan yang ditandai dengan adanya proses belajar-mengajar yang terbuka dan penuh dialog yang sehat dan bertanggungjawab. Suasana humanis dalam pendidikan akan mengantarkan tercapainya tujuan pendidikan Islam. Berangkat dari wacana tersebut, kajian mengenai pendidikan Islam dan pendidikan politik sangat signifikan untuk ditelaah lebih lanjut dalam relevansinya dengan konteks keindonesiaan, terutama untuk mewujudkan harmonisasi kehidupan umat beragama di Indonesia melalui dialog antar umat beragama.

\section{Islam dan Demokrasi}

Tarik menarik pemahaman mengenai relasi antara Islam dan demokrasi sampai saat ini masih terus terjadi. Terdapat tiga paradigma yang mendasari relasi Islam dan demokrasi ini: pertama, model paradoksal, di mana antara Islam dan demokrasi tidak bisa dipertemukan bahkan cenderung berlawanan. Kedua, model sekular, di mana hubungan antara Islam dan demokrasi bersifat netral, karena urusan agama dan politik termasuk masalah demokrasi berjalan sendiri-sendiri. Ketiga, model teo-demokrasi yang menyatakan bahwa Islam dan demokarsi mempunyai kesejajaran dan kesesuaian, sehingga agama dalam hal ini baik pada tataran teologis maupun sosiologis sangat mendukung proses demokratisasi (Hidayat, 1994, hal. 190-194).

Demokrasi mewacanakan adanya pengakuan akan pentingnya peran agamatermasuk Islam di dalamnya. Kedudukan agama terhadap proses demokratisasi sangat dilematis, satu sisi demokrasi hadir sebagai pendorong aktif, di sisi lain yang lain agama menjadi faktor penghambat. Hal penting yang diambil dari Islam adalah nilai-nilai yang menekankan perlunya sikap toleransi, kesamaan, kesederajatan, keadilan dan saling menghargai antar elemen bangsa yang beragam dalam proses berdemokrasi. Meskipun agama tidak secara sistematis mengajarkan praktik demokrasi, namun agama senantiasa menjadi etos, spirit, dan muatan doktrinal bagi tumbuhnya kehidupan demokratis.

Sebagai contoh dalam Islam terdapat konsep dengan istilah syura' (QS. Ali Imran: 159) (Sulaiman, 1998, hal. 98). Prinsip syura' dalam Islam berdasarkan kepada tauhid dan nilai-nilai kebenaran (Rahman, 1980, hal. 83). Tujuan utama alQuran tersebut adalah nilai-nilai dan perintah etik sosial kemasyarakatan dijunjung tinggi dan bersifat mengikat dalam kegiatan-kegiatan sosio-politik umat manusia. Nilai-nilai ini secara substantif bertalian secara organik dengan prinsip-prinsip 
keadilan (QS. an-Nisa'; 135), persamaan (QS. al-Hujurat: 13), dan kemerdekaan (QS. at-Taubah: 105), dan prinsip keumatan lainnya yang menjadi ajaran moral dalam alQuran. Oleh karena itu, keharusan menegakan nilai-nilai etik-moral dari al-Quran menjadi keharusan bagi umat Islam, kapan dan dimanapun berada dengan cara yang positif-konstruktif. Pada titik inilah letak ruang gerak dari penafsiran-pemahaman yang harus selalu dikontekstualisasikan dengan perkembangan realitas yang ada. Dalam konteks Islam, nilai demokrasi merupakan nilai yang sejalan dengan alQuran yang terfokus pada upaya untuk meningkatkan harkat dan martabat umat manusia.

\section{Menuju Pendidikan Islam Humanis}

Gerakan demokratisasi yang dibangun oleh pemikir pendidikan Islam merupakan upaya untuk membangun dasar-dasar persamaan, kebebasan, keadilan, keterbukaan dan anti diskriminasi. Oleh karena itu, penting sekiranya pendidikan silam menerapkan sistem pengajaran yang berorientasi pada penanaman kesadaran kritis agar mampu membangun frame work yang memungkinkan untuk memahami berbagai persoalan hidup yang ada. Kurikulum menjadi hal yang mendasar dalam hal ini, karena kurikulum sebagai media yang menunjang proses belajar peserta didik yang demokratis, pluralis, menekankan penghayatan hidup serta refleksi untuk menjadi manusia yang utuh dan mampu menghormati hak-hak orang lain.

Kurikulum dalam pendidikan Islam hendaknya ditekankan pada proses, yang mengindikasikan pada 4 hal agar terjadi kegiatan belajar yang demokratis yaitu: pertama, posisi belajar peserta didik sebagai subjek dalam belajar; kedua, cara belajar peserta didik ditentukan oleh latar belakang budayanya; ketiga, latar belakang budaya peserta didik menjadi entry behaviour kulturnya; keempat, lingkungan belajar peserta didik sebagai sumber belajarnya (Hasan, 2000, hal. 510). Dalam hal ini kurikulum pendidikan Islam seharusnya mencakup toleransi, tema-tema tentang perbedaan etno-kultural dan agama, demokrasi dan pluralitas, kemanusia universal, dan nilai-nilai keterbukaan lainnya.

Pendidikan Islam pada konteks ini seharusnya mengedepankan karakter dasarnya sebagai basic values, yakni: pertama, pendidikan tidak mendikotomikan antara ilmu umum (human science) dan ilmu-ilmu keagamaan ('ulum al-din, theology science). Kedua, pendidikan Islam haruslah mempunyai karakter pendidikan yang berbasis pluralitas; ketiga, pendidikan Islam haruslah menjadi lembaga pendidikan yang menghimpun dan menghidupkan sistem demokrasi dalam pendidikan.

Pendidikan hendaknya mengarahkan pada situasi belajar yang saling menemani, saling belajar dalam kehidupan sehingga memungkinkan terjadinya dialog untuk membuka wawasan kehidupan masyarakat. Berangkat dari tujuan pendidikan Islam, bagaimana kedudukan pendidik dan peserta didik, sampai konsep demokrasi maka pendidikan humanis dapat terwujud dengan memahami definisi-definisi di atas dan mewujudkan pada tataran praktis dunia pendidikan (Azra, 1998, hal. 79). Konsep pendidikan yang digagas kalangan praktisi pendidikan 
Islam dapat diimplementasi dari demokratisasi dan jika itu diaplikasikan maka akan terwujud pendidikan Islam yang humanis. Saling menghormati, saling menghargai, saling menyayangi dan saling memahami adalah keniscayaan dalam membangun pendidikan Islam yang humanis. Melalui demokrasi pendidikan di mana siswa turut aktif dalam menentukan proses belajar mereka, siswa dan guru sebagai subjek pendidikan yang sama-sama bisa belajar sehingga mampu mengembangkan berpikir kritis dan kreatif siswa maka tidak ada lagi guru sebagai otoritas tertinggi dalam proses pembelajaran siswa seolah-olah sistem ini mengukung daya kritis dan kreatif siswa.

Pendidikan Islam yang mengedepankan konsep yang memandang manusia seutuhnyajika dikaitkan dengan proses pendidikan berartiberusahamengoptimalkan segenap kefitrahan (potensi kognitif, afektif dan psikomotorik) manusia untuk mewujudkan kesejahteraan eksistensi kehidupan manusia di dunia yang dilandasi dengan nilai-nilai ajaran Islam. Sehingga pendidikan Islam yang humanis akan terwujud jika diterapkannya sikap menjunjung tinggi dan mengoptimalkan berbagai fitrah manusia dalam rangka mewujudkan insan kamil dan bermanfaat bagi diri sendiri dan orang lain (Baharuddin, 2007, hal. 15). Eksistensi manusia pun akan tercipta sebagai makhluk yang humanis. Pendidikan Islam yang humanis harus menjadi orientasi dan aplikasi dalam praktek pendidikan. Semua kegiatan pendidikan harus memiliki amplikasi dengan tugas kehidupan manusia di dunia yaitu sebagai khalifah di muka bumi.

Oleh karenaitu, demokratisasi pendidikan Islam merupakan suatu wujud upaya sistem pendidikan yang mampu menciptakan suasana humanis dalam pendidikan. Dalam gagasan demokrasi dalam pendidikan Islam ada muatan-muatan sistem pendidikan, di mana pendidik dan peserta didik dapat mengembangkan potensinya dan kreatifitasnya tanpa ada pengekangan atau intimidasi dari pihak manapun. Pendidik yang memahami kedudukan dan kewajibanya sebagai pendidik serta memahami kedudukan peserta didik sehingga mengetahui apa saja yang dibutuhkan siswa harus diperhatikan untuk menerapkan demokasi pendidikan. Demokrasi dapat diterapkan melalui metode-metode pembelajaran yang menyenangkan sehingga mampu membangkitkan dan mengembangkan segenap kompetensi siswa (Azra, 1998, hal. 17). Konsep yang memandang manusia seutuhnya jika dikaitkan dengan proses pendidikan berarti beusaha mengoptimalkan segenap kefitrahan (potensi kognitif, afektif dan psikomotorik) manusia untuk mewujudkan kesejahteraan eksistensi kehidupan manusia di dunia yang dilandasi dengan nilai-nilai ajaran Islam.

Untuk menuju pada pendidikan humanis, pendidikan Islam perlu membangun konsep pendidikan yang dapat mengembangkan sumber daya manusia yang berkualitas yang dilandasai dengan nilai-nilai ilahiyah, kemanusian (insaniyah), masyarakat, lingkungan dan berbudaya. Dari kerangka pemikiran ini, maka pendidikan Islam harus mengembangkan pendidikan yang integralistik, humanistik, pragmatis, dan berakar pada budaya. Konsep pendidikan yang Integralistik, secara utuh berorientasi pada nilai-nilai Ketuhanan (Rabbaniyah- 
ilahiah), nilai-nilai kemanusiaan (insaniyah) dan alam (alamiyah) pada umumnya sebagai suatu yang integralistik bagi perwujudan kehidupan rahmatan lil 'alamin. Konsep pendidikan humanistik, pendidikan yang berorieintasi dan memandang manusia sebagai manusia (humanisasi) dengan menghargai hak-hak asasi manusia, hak untuk menyuarakan pendapat, mengembangkan potensi berpikir, berkemauan dan bertindak sesuai dengan nilai-nilai luhur kemanusiaan.

Pendidikan Islam yang di dalamnya ada pendidikan pragmatis, memandang manusia sebagai makhluk fungsional yang perlu melangsungkan, mempertahankan, mengembangkan hidupnya baik secara jasmani maupun rohani serta mewujudkan manusia yang sadar akan kebutuhan-kebutuhan hidupnya dengan memiliki kepekaan terhadap masalah-masalah kemanusiaan. Konsep pendidikan berakar pada budaya, dapat mewujudkan manusia yang memahami eksistensinya dengan memiliki kepribadiaan yang unggul, harga diri, percaya pada kemampuan sendiri, membangun budaya berdasarkan budaya sendiri yang didasarkan pada nilainilai Ilahiyah. Dari kerangka ini, kompetensi yang dikembangkan dalam proses pendidikan Islam harus berbasis kepada kompetensi nilai-nilai Ilahiyah, knowledge, skill, ability, sosial-kultural dan secara operasional dapat terintegrasi dengan masyarakatnya, lingkungan sosial-kulturalnya, dan selalu menerima dan ikut serta melakukan perubahan.

Sebagai agama yang mengusung konsep rahmatan lil 'alamin, perubahan pendidikan Islam tidak bersifat tambal sulam yang didasarkan pada kebutuhan dan keinginan yang bersifat sementara, tetapi harus merupakan upaya strategis, terencana dan menyeluruh yang dapat mewujudkan peningkatan kualitas iman Ilahiyah yang aplikatif, pengetahuan dan keterampilan professional, pendidikan sebagai proses pembebasan, proses pencerdasan dan mewujudkan peserta didik berwawasan integratife, proses pemberdayaan potensi manusia, menjunjung tinggi hak-hak anak, menghasilkan manusia demokratis serta menghasilkan manusia cinta perdamaian dan perduli lingkungan. Intinya, pendidikan Islam harus berupaya untuk membangun pendidikan yang relevan dan bermutu sesuai dengan kebutuhan kehidupan manusia.

\section{Nilai Humanisme Sebagai Dasar Pendidikan Politik}

Humanisme merupakan sebuah proses pembebasan manusiawi atau yang dikenal dengan transformasi struktural non-revolusioner. Menurut Islam humanis bahwa setiap agama termasuk Islam menyimpan kekuatan pembebasan, namun dunia juga mempunyai mekanisme perubahan tersendiri sehingga bahaya ketika agama diturunkan pada teknik dan penentu pembebasan, karena agama bisa menjelma menjadi institusi kekuasaan yang menindas atas nama otoritas agama (Wahid, 1989, hal. 9).

Nilai humanisme yang menjadi dasar pendidikan politik dalam Islam mensyaratkan setiap komunitas agama memiliki kesetaraan. Kesetaraan tersebut meliputi: pertama, negara akan menegakkan kesetaraan seluruh komunitas 
beragama dihadapan hukum. Kedua, komunitas beragama secara sendiri-sendiri atau bersama-sama meminta negara untuk berdialog dengan mereka mengenai masalah yang penting. Ketiga, tidak akan ada diskriminasi berdasarkan afiliasi keagamaan dalam praktik pemerintahan (Esaac, 2000, hal. 334).

Pendidikan politik sebagai aspek paling penting bagi upaya menumbuhkan sikap dan perilaku demokratis maka perlu didasari prinsip humanisme. Dalam hal ini tujuannya adalah bagaimana mendidik siswa dan masyarakat agar dapat berpikir kritis. Proses ini dilakukan untuk membangun adanya kebebasan dalam pendidikan yang akan terwujud melalui demokratisasi pendidikan di masyarakat. Dalam lingkup kecil di sekolah misalnya upaya menciptakan demokrasi pendidikan ditandai dengan adanya proses belajar-mengajar yang terbuka dan penuh dialog yang sehat dan bertanggungjawab antara pendidik dan peserta didik. Pendidikan Politik yang didasarkan pada aspek humanisme ini mensyaratkan adanya pemahaman menganai hakikat manusia. Agar manusia dapat mencapai atau mendekati kesempurnaan, dan mencapai tujuan hidup, ada empat kriteria yang mesti dimiliki, yakni: memiliki kepandaian yang cukup, keyakinan agama yang kuat, akhlak yang terpuji, dan memiliki watak dan kecenderungan yang menghormati dan menjalin persaudaraan antar manusia.

Untuk mewujudkan pendidikan yang demokratis dan humanis, maka kerangka acuan pemikiran dan pengembangan sistem pendidikan politik harus mengedepankan prinsip-prinsip yang mampu mendukung gagasan tersebut seperti kesetaraan, kejujuran dan keadilan. Menurut Jalal (2001, hal. 17), prinsip tersebut antara lain: pertama, pendidikan harus membangun prinsip kesetaraan. Kedua, pendidikan merupakan wahana pemberdayaan masyarakat. Ketiga, prinsip pemberdayaan masyarakat harus digunakan untuk memaksimalkan peran dan fungsi pendidikan dalam pengembangan potensi manusia. Keempat, prinsip kemandirian. Kelima, prinsip toleransi dan konsesus di tengah masyarakat yang plural. Keenam, prinsip pendidikan yang diarahkan pada peserta didik sebagai subjek dan ketujuh, prinsip pendidikan multikultural.

Dengan demikian, perlu adanya rekonstruksi pendidikan politik untuk memperteguh dimensi kontrak sosial-keagamaan dalam pendidikan agama (Abdullah, 1999, hal. 13). Maka pendidikan politik harus diorientasikan kepada: pertama, humanisasi pendidikan berakar dari keunikan personalitas anak manusia. Kedua, humanisasi pendidikan dapat dijalankan dengan bentuk demokratisasi pendidikan. Demokratisasi pendidikan menjadi syarat mutlak bagi terbentuknya suasana dialogis dan humanis. Di dalam proses sosial di masyarakat hendaknya dijalankan dengan penuh keterbukaan, peserta mendapat kesempatan penuh untuk mengekspresikan dirinya. Begitu juga hubungan antara guru dan siswa. Hubungan itu dibangun atas kemitraan, bukan sebagai atasan dan bawahan, melainkan merupakan partner dalam mengantarkan proses belajar mengajar untuk menemukan kesadaran hidup. 


\section{Tujuan Pendidikan Politik: Pendidikan Kesetaraan dan Berkeadilan}

Pendidikan politik menjelaskan bahwa demokrasi merupakan suatu proses karena demokrasi tidak dipandang sebagai suatu sistem yang sudah final dan sempurna. Karena itu, sifatnya yang belum selesai maka akan selalu timbul reaksi sebagai alasan apologia bagi sistem yang ada (Barton, 1998, hal. 427). Keadaan suatu demokrasi selalu mengalami perubahan sesuai dengan perkembangan sosial politik suatu negara dan tergantung dari imbangan kekuatan yang berlaku. Pendidikan politik mengindikasikan demokrasi sebagai alternatif bagi pengembangan sistem nilai dalam berbagai lapangan kehidupan manusia baik dalam kehidupan keluarga, masyarakat maupun negara. Hal ini dikarenakan hampir semua negara di dunia ini menjadikan demokrasi sebagai asas yang fundamental dan esensial, yang secara paradigmatik telah memberikan arah bagi peranan masyarakat untuk menyelenggarakan negara sebagai organisasi tertinggi.

Perlu sekiranya pendidikan politik menempatkan demokrasi sebagai dasar hidup bernegara, yang memposisikan masyarakat atau rakyat sebagai pemegang kekuasaan, pembuat, penentu keputusan, kebijakan serta pelaksaannya selalu berada di bawah kontrol masyarakat. Karena itu, negara yang demokratis mengindikasikan jika mekanisme pemerintahnya mewujudkan prinsip-prinsip dan nilai-nilai demokrasi, baik itu persamaan, kebebasan dan pluralisme.

Dalam kehidupan sosial yang plural, nilai-nilai demokrasi ada yang bersifat pokok dan ada yang merupakan nilai derivasi dari nilai pokok tersebut. Karena itu ada tiga nilai pokok dalam demokrasi, yaitu: kebebasan, keadilan dan musyawarah (Aziz, 1999, hal. 65). Kebebasan dalam konteks ini merupakan bentuk kebebasan individu dihadapan kekuasaan negara atau hak-hak individu warga negara dan hak kolektif dari masyarakat. Keadilan merupakan salah satu landasan demokrasi, dalam pengertian terbukanya peluang kepada semua orang dan juga ekonomi atau kemandirian dari orang yang bersangkutan untuk mengatur hidupnya sesuai dengan apa yang ia ingini. Keadilan menjadi nilai penting karena berkaitan dengan seseorang mempunyai hak menentukan jalan hidupnya, tetapi orang tersebut harus dihormati haknya dan diberi peluang serta kemudahan untuk mencapainya. Keadilan akan terwujud ketika orang tidak melihat halangan untuk mengekspresikan cita-cita dan keinginannya. Sedangkan musyawarah, merupakan bentuk atau cara memlihara kebebasan dan memperjuangkan keadilan tersebut lewat jalur permusyawaratan (Wahid, 1993, hal. 90).

Dalam konsep pendidikan politik berbasis pemikiran Islam humanis, paham demokrasi dan misi agama mempunyai kesamaan yang kuat, mengingat agama mempunyai kepentingan untuk menegakkan keadilan bagi kesejahteraan rakyat. Karenanya, agama dapat berjalan seiring dengan demokrasi selama melakukan transformasi bagi dirinya, secara intern maupun ekstern. Untuk dapat melakukan transformasi intern itu agama harus merumuskan kembali pandangannya mengenai martabat manusia, kesejajaran kedudukan semua manusia di muka undangundang dan solidaritas hakiki antar sesama umat manusia (Wahid, 1994, hal. 273). 


\section{Pendidikan Islam, Pendidikan Politik, Dan Dialog Antar Umat Beragama Di Indonesia}

Pendidikan politik Islam dalam melakukan elaborasi pemikiran ditujukan untuk pengaplikasian demokrasi, bahwa suatu negara dapat dikatakan demokratis selama mampu menjamin hak-hak dasar asasi manusia, yaitu: jaminan keselamatan fisik, jaminan keselamatan keyakinan agama, jaminan kehidupan keutuhan rumah tangga, jaminan keselamatan hak milik, dan jaminan keselamatan akal.

Umat Islam Indonesia harus mewarisi semangat pluralisme yang tinggi, dengan menunjukkan sikap positif terhadap pluralisme adalah suatu keharusan, tetapi terlebih karena tuntutan objektif dari realitas kehidupan modern. Pendidikan politik dalam Islam hendaknya melihat hubungan antara Islam dan pluralisme dalam konteks manifestasi universalisme dan kosmopolitanisme ajaran Islam, mengingat Islam menjamin lima hak dasar kemanusiaan, yaitu; keselamatan fisik warga masyarakat dari tindakan di luar hukum, keselamatan keyakinan agama tanpa paksaan, keselamatan keluarga dan keturunan, keselamatan harta benda dan milik pribadi, serta keselamatan profesi (Wahid, 1995, hal. 546).

Di sisi lain, pendidikan politik juga banyak menyoroti pluralisme dalam tinjauan sosiologis. Berdasarkan kondisi demokrasi di Indonesia, ia melihat bahwa demokratisasi, toleransi dan kerukunan hidup beragama berjalan cukup baik, karena Islam masuk dengan corak yang lebih akomodatif terhadap budaya lokal, termasuk kepercayaan-kepercayaannya sehingga terjadi akluturasi budaya yang kompleks (Wahid, 1992, hal. 6). Tradisi kerukunan hidup beragama di Indonesia telah menjadi bangunan politik yang stabil dan mantap yang ditandai dengan adanya interaksi sosial yang harmonis antar pemeluk agama. Meskipun demikian, watak normatif Islam jelas-jelas kosmopolitanis didukung sejumlah pengalaman sejarah, tetapi hal tersebut tidaklah berjalan mulus. Dalam konteks pembangunan toleransi beragama, belakangan ini umat Islam Indonesia mengalami suatu gejala yang dikenal dengan proses pendangkalan agama (Wahid, 1998, hal. 51-52).

Pada dasarnya demokrasi bukan hanya menyangkut sistem politik pada tingkat negara, dan lebih dari itu bahwa demokrasi juga mencakup kehidupan keseharian masyarakat. Proses demokrasi harus tercermin dalam interaksi antar kelompok dan golongan dalam masyarakat, karena pola kehidupan keluarga, bahkan hubungan antar individu harus didasarkan pada sistem demokrasi. Dalam pengertian lain bahwa demokratisasi harus dimulai dari ruang terkecil dalam interaksi masyarakat, baik pada tataran individu, struktur relasi kekuasaan juga menentukan esensi dan kualitas demokrasi level di atasnya yaitu masyarakat dan Negara (Wahid, 1999, hal. 30). Proses demokrasi akan berlangsung lebih baik jika setiap individu memiliki pengetahuan yang memadai tentang nilai-nilai demokrasi. Kedua tataran inilah yang menentukan karakteristik demokrasi modern sebagaimana disampaikan Huntington bahwa demokrasi mendasarkan pada negara-kebangsaan. Ia mencitacitakan terciptanya tatanan masyarakat dunia yang dapat saling berdiri sejajar tanpa harus terdistorsi oleh ruang-ruang kesukuan maupun keagamaan.

Persoalan pembangunan demokrasi yang lebih substantif di atas harus dicarikan relevansinya dengan orientasi Islam yang ada saat ini. Tanpa pencarian 
yang serius maka tetap akan mendatangkan silang pendapat dan kekerasan akan terus terjadi. Untuk mencapai semua harus ada keberanian untuk melepaskan paham keagamaan kita dari muatan-muatan kepentingan politik sesaat, sebab segala kepentingan politik hanya akan mereduksi semangat kenabian yang bawa oleh agama. Secara prinsip, al-Quran akan menjadi nilai-nilai luhur yang merujuk pada kemaslahatan umat beragama (Effendi, 1994, hal. 55).

\section{Dari Pendidikan Politik Menuju Dialog Umat Beragama di Indonesia}

Secara prinsip, pendidikan politik pada dasarnya mensyaratkan adanya ruang demokratisasi, sebagai sarana untuk membangun masyarakat yang dialogis. Tujuan akhir pendidikan politik adalah pada perubahan prilaku serta sikap, kualitas dan berbagai aspek yang mendorong adanya ruang humanisme. Pendidikan politik hendaknya diorientasikan untuk menanamkan nilai-nilai demokratis seperti keterbukaan, perasaan saling menghargai, simpati, empati, solidaritas, dan adanya pemahaman pluralisme dalam kehidupan masyarakat Indonesia yang majemuk. Realitas yang majemuk seperti menjadi sumber konflik sosial keagamaan masyarakat Indonesia. Dalam tinjauan sosiologis, pluralisme keagamaan di satu sisi merupakan kekayaan yang berharga, di sisi lain adalah persoalan serius yang memerlukan kearifan dalam mensikapinya, sebab pluralisme seringkali menjadi pemicu konflik sosial keagamaan. Kesadaran pluralisme masih sangat mahal di Indonesia (Misrawi, 2008, hal. 205). Pluralisme agama sebenarnya mengajarkan agar lebih realistis dalam melihat kenyataan sosial yang ada. Indonesia merupakan negara yang memiliki keragaman baik agama maupun budaya. Pluralisme agama adalah suatu kenyataan, kita adalah berbeda, beragam, dan plural dalam hal beragama. Pluralisme adalah kenyataan sosial, sesuatu yang niscaya dan tidak dapat dipungkiri lagi.

Sebagai kenyataan sosial, pluralisme jika tidak dikelola secara baik akan memunculkan konflik sosial. Untuk itu dibutuhkan dialog yang merupakan jalan manusiawi untuk menyelesaikan persoalan yang muncul diantara beberapa pihak yang memiliki pandangan berbeda. Dalam hal ini dialog antar umat beragama merupakan dialog yang dilakukan antar mereka yang memiliki pandangan keimanan yang berbeda-berbeda. Dialog antar umat beragama yang efektif harus mampu menghasilkan perubahan kesadaran atas keimanan satu dengan yang lain menjadi patner dialog, dan harus mampu menumbuhkan perubahan sikap kita. Adanya pertumbuhan dan perubahan tersebut diharapkan dialog akan menghasilkan kesepakatan yang produktif dalam kehidupan umat beragama.

Dialog antar umat beragama, sebagaimana yang pernah terjadi dalam rentang sejarah, harus dilihat sebagai momen yang istimewa dalam sejarah relasi umat beragama dan interaksi pada umumnya. Menurut Huntington (1993, hal. 12), unsur-unsur pembatas objektif adalah bahasa, sejarah, agama, adat istiadat, dan lembaga-lembaga. Unsur pembatas subjektifnya adalah identifikasi dari manusia. Perbedaan antar pembatas itu adalah nyata dan penting. Secara tidak sadar, manusia terkelompok ke dalam identitas-identitas yang membedakan antara satu dengan 


\section{Pendidikan Islam, Pendidikan Politik, Dan Dialog Antar Umat Beragama Di Indonesia}

lainnya. Dari klasifikasi di atas, agama merupakan salah satu pembatas peradaban. Umat manusia terkotak dalam agama Islam, Kristen, Katolik, Konghucu, dan sebagainya.

Suatukomunitas masyarakat tidakbisahidup sendiritanpa mauberkomunikasi, berdampingan dengan komunitas lainnya, termasuk untuk kelompok keagamaan dalam era global saat ini. Leonard Swider sebagaimana yang dikutip Alwi Shihab, kita tidak dapat mengabaikan pihak lain dengan menutup mata, pikiran, dan hati kita pada mereka. Apalagi menatap mereka dengan perasaaan penuh curiga, prasangka, bahkan dengan kebencian. Pola hubungan ini hanya akan mengantarkan kita pada permusuhan yang akan berakhir dengan konfrontasi (Shihab, 1999, hal. 67). Disinilah Swider secara jelas menekankan pentingnya dialog antar komunitas, baik itu masyarakat maupun komunitas agama. Mengabaikan dialog sama saja dengan memperpanjang perasaan saling curiga, memperkuat rasa benci dan mengabaikan keberadaan orang lain di luar kita dan komunitas kita. Keberadaan komunitas lain di luar diri kita harus tetap kita apresiasi untuk memperkaya khasanah kehidupan kita, mempertinggi moralitas kita sebagai manusia.

Dialog antar umat beragama merupakan dialog dari berbagai pihak kalangan agamawan. Di satu sisi untuk mengungkapkan pandangan agama sendiri secara tepat, disisi lain untuk mendengarkan pandangan mitra dialog mereka secara terbuka, tanpa sikap a priori (Rahman, 2007, hal. 321). Dialog antar umat beragama bukan ajang untuk berdebat, berapologi, bahkan pemaksaan pandangan diri sendiri terhadap pihak lainnya. Sebaliknya, peserta dialog bisa saling belajar satu dengan lainnya mengenai pengalaman kehidupan keberagamaan mereka. Dengan dialog membuka kemungkinan masing-masing peserta dialog mengalami perubahan cara pandang dalam berinteraksi antara satu dengan lainnya secara lebih terbuka, setidaknya akan bisa memahami keyakinan, pemikiran dan masalah yang dihadapi oleh mitra dialog.

Sebagai kenyataan sosial, dialog antar umat beragama tidak dapat dipisahkan dari persoalan hidup yang dialami oleh peserta dialog. Realitas sosial merupakan fokus pembicaraan dalam dialog antar umat beragama ini. Tujuan dialog ini adalah pembicaraan bersama atas dasar saling pengertian dan menghargai, kemudian bersama-sama membagun hubungan berdasarkan kejujuran, keterbukaan dan komitmen untuk menjalankan keputusan bersama. Dialog bukan untuk membandingkan perbedaan atau mengukur benar tidaknya ajaran atau keyakinan perserta dialog akan tetapi diarahkan untuk mencari persamaan-persamaan yang bisa dijadikan sebagai landasan saling pengertian dan kerjasama dalam masyarakat. Dalam dialog antar umat beragama terdapat asas dan tujuan bagi kerjasama antar umat beragama untuk mencapai keadilan, kemerdekaan, persatuan, kerukunan, kemakmuran, dan perdamaian bersama (Budiyono, 1973, hal. 84).

Pendidikan politik dalam Islam secara paradigmatik mendorong umat beragama untuk menghargai perbedaan yang ada. Pertama, dialog bukan untuk mencari kebenaran sendiri, tetapi untuk memperkaya pengalaman keberagamaan 
masing-masing peserta dialogyangkemudian dijadikan sebagai media memampukan diri. Dialog tidak hanya sebatas perjumpaan antar pemeluk agama yang berbeda saja, tetapi juga memiliki spirit kemanusiaan, bahwa komunitas lain di luar kita juga memiliki pengalaman beragama yang bisa diserap, digunakan untuk memperkaya kehidupan kita. Kedua, dialog merupakan upaya untuk melakukan tukar pengalaman kehidupan keberagamaan di antara peserta dialog. Pengalaman keagamaan ini dirasa penting untuk didialogkan demi mencapai titik temu bersama dalam bingkai kerjasama antar agama. Di sini pengalaman beragama atau spiritualitas masingmasing agama bisa bersifat universal, tidak parsial. Ketiga, bagi peserta dialog, dengan dialog akan mengembalikan hakikat agama sebagai agama yang damai, saling mengasihi, dan saling menghormati. Disinilah Islam sebagai rahmatan lil álamin tidak mungkin dikembangkan tanpa gerakan moderasi, karena setiap gerakan eksklusif akan melahirkan benturan. Moderasi berarti keseimbangan antara keyakinan dan toleransi. Bagaimana orang memiliki ketaatan terhadap agamanya di satu sisi, tetapi disisi lain ia memiliki toleransi cukup tinggi. Sikap tengah bukan berarti tidak memiliki pendirian, karena ia tetap memiliki komitmen terhadap masalah keadilan, kemanusiaan, dan persamaan. Justru hal ini ini merupakan substansi nilai agama yang harus diperjuangkan, tetapi model perjuanggannya secara moderat (Ali, 2008, hal. 30). Hal tersebut sebagai upaya untuk membangun spirit mutual understanding untuk memberi dan menerima klarifikasi dalam proses dialog, sehingga agama satu dengan yang lain dapat mengklarifikasi fitnah dan salah pengertian terhadap keyakinan agama-agama lain.

Pandangan pluralis yang dikembangkan oleh pendidikan politik Islam untuk dialog antar umat beragama terlihat diikuti oleh adanya pandangan keterbukaan untuk menemukan kebenaran dimanapun juga (Wahid, 1981, hal. 3). Dalam pendidikan politik Islam, pandangan pluralis harus diwujudkan dalam bertindak dan berpikir, sebab dua hal ini yang bisa melahirkan toleransi. Sikap toleran tidak bergantung pada apapun, tetapi pengakuan atas pluralitas merupakan persoalan hati, persoalan perilaku (Barton, 1999, hal. 398). Pemikiran dialog antar umat beragama selaras dengan pemikiran Gus Dur yang mengembangkan pandangan anti eksklusivisme agama. Menurutnya, berbagai peristiwa kerusuhan yang berwajah agama dibeberapa tempat di Indonesia adalah akibat adanya eksklusivisme agama (Wahid, 1998, hal. 52).

Untuk membangun relasi antar umat beragama yang tidak sempit dan sektarian pendidikan Islam mengungkapkan perlunya sikap beragama yang saling menyantuni. Esensi saling menyantuni ini terletak pada sikap dimana kita bisa saling mengoreksi. Jadi sikap santun tidak boleh dengan standar ganda atau tidak boleh mengabaikan keadilan kepada siapa pun, termasuk orang berlainan agama (Wahid, 1998, hal. 53). Apa yang disampaikan Gus Dur ini sebenarnya lebih merupakan otokritik bagi umat Islam sendiri, karena kuatnya gejala politisasi agama dan pendangkalan agama di Indonesia. Namun membangun pemahaman yang demikian tidaklah mudah, sebab dalam relasi antar agama masih banyak persoalan yang bisa menghambat adanya dialog antar agama. 


\section{Pendidikan Islam, Pendidikan Politik, Dan Dialog Antar Umat Beragama Di Indonesia}

Kerukunan umat beragama mengindikasikan terciptanya suatu hubungan yang harmonis dan dinamis serta rukun dan damai diantara sesama umat beragama di Indonesia, yakni hubungan harmonis antarumat beragama, antara umat yang berlainan agama dan antara umat beragama dengan pemerintah dalam usaha memperkokoh persatuan dan kesatuan bangsa serta meningkatkan amal untuk bersama-sama membangun masyarakat sejahtera lahir dan batin. Kerukunan hidup beragama menunjukkan pola hubungan antar berbagai kelompok umat beragama yang rukun, saling menghormati, menghargai dan damai, tidak bertengkar dan semua persoalan dapat diselesaikan sebaik-baiknya dan tidak mengganggu kerukunan hubungan antarumat beragama pada suatu daerah tertentu.

Kaitannya dengan upaya membangun kerukunan antar umat beragama, pengertian toleransi ada yang ditafsirkan secara negatif (negative interpretation of tolerance) dan ada yang positif (positive interpretation of tolerance). Penafsiran yang negatif hanya mensyaratkan cukup dengan membiarkan dan tidak menyakiti atau tidak mengganggu orang lain atau kelompok lain. Namun bagi penafsiran yang positif, toleransi tidak cukup hanya membiarkan atau tidak menganggu, tetapi lebih dari itu toleransi membutuhkan bantuan, dorongan, dukungan dan penghargaan terhadap eksistensi orang lain atau kelompok lain. Dengan pengertian yang positif ini, maka kerukunan akan tercapai.

Agama dapat mampu menunjukkan peranannya dalam mengintegrasi dan menciptakan harmonisasi sosial dalam masyarakat. Hal ini karena agama mendorong nilai-nilai kerukunan dan penghormatan kepada orang lain. Di sisi lain, keberadaan agama sebagai fenomena teologis juga memiliki potensi konflik. Keragaman budaya dan agama merupakan peluang sekaligus tantangan; pluralitas sosial, agama dan budaya memberi kemungkinan untuk memperkaya masing-masing pihak sekaligus sumber pertentangan identitas sosial, budaya, dan agama. Di dalam setiap agama melekat dua sifat, yaitu bersifat inklusif, universal dan transending, sekaligus bersifat ekslusif, partikular, dan primordial. Oleh karena itu, apakah akan menjadi peluang yang mengkayakan pengalaman sosial, kebudayaan, dan keagamaan, menjadi dukungan moral, etika, da spiritual yang positif bagi masyarakat dan bangsa ini; atau malah akan menjadi pemicu keretakan, perpecahan dan konflik, menjadi tergantung pada kemampuan masarakat dan bangsa ini untuk mengelola pluralitas tersebut.

Interaksi antar umat beragama mencerminkan bagaimana agama difungsionalkan dalam konteks sosial. Dalam proses sosial ini, maka kondisi damai dan konflik menjadi bagaikan dua sisi mata uang dalam kehidupan manusia. Manusia berhubungan dengan pihak lain dapat berelasi secara asosiatif, tetapi dapat juga dissosiatif. Interaksi yang assosiatif adalah hubungan sosial dalam masyarakat terwujud dari adanya kehendak rasional antarelemen masyarakat, dalam pengertian segala hal yang disepakati bersama dan tidak bertentangan dengan norma dan nilai sosial yang berlaku. Proses ini mengarah pada semakin kuatnya ikatan antara pihakpihak yang berhubungan. Proses ini meliputi bentuk kerjasama, dan akomodasi. Di sisi lain, interaksi dissosiatif merupakan bentuk hubungan sosial yang mengarah 
pada perpecahan atau merenggangnya hubungan sosial antarpihak yang saing berhubungan. Proses ini dapat berbentuk persaingan, kontravensi, maupun pertentangan.

Pemahaman tentang kata agama masih menimbulkan beberapa penafsiran yang berbeda-beda. Kadang masih rancu dalam memahami agama sebagai ajaran da agama sebagai sebuah institusi. Nama agama adalah adalah nama dari institusi religius seperti Islam, Kristen, Budha, Hindu, dan Khonghucu. Sedangkan ajaran agama adalah pesan-pesan yang harus dilakukan dan ditinggalkan oleh semua penganut agama. Selama ini kebanyakan dari masyarakat kita menganggap agama sebagai Tuhan. Meskipun juga tidak bisa dikatakan bahwa mereka mengesampingkan ajaran agama. Pemahaman seperti ini sedikit banyak mempengaruhi bahwa yang terpenting adalah membela institusi agama dan bukan menegakan ajaran agamanya. Agama akan berubah fungsi ketika penganutnya menjadikannya bukan sebagai kebutuhan batiniah, tetapi sekarang berubah menjadi alat untuk meraih tujuan individu maupun kelompok. Terlebih lagi apabila agama dipakai sebagai identitas penyekat antara satu masyarakat dengan masyarakat lainnya, sehingga terjadi pilarisasi yang membentuk kelompok-kelompok tertentu. Sehingga bisa memunculkan sikap eksklusif dalam beragama. Tetapi sifat eksklusif ini tidak diletakan pada jalur yang benar, tentang meyakini kebenaran ajaran yang dia anut, hanya sebatas pada pembelaan kelompok yang dipandangnya dirinya berada didalamnya, sehingga unsur in group muncul dalam dirinya. Akan berbahaya sekali apabila sikap eksklusif dan in group ini kemudian menganggap orang di luar dirinya dan kelompoknya, atau out group akan dianggap salah bila tidak sama dengan pandangan dia terhadap agama. Pandangan eksklusif yang tidak benar adalah apabila menganggap bahwa hanya agama kita lah yang paling benar, sedangkan agama lainnya adalah salah.

Sikap inklusif dalam beragama adalah hal utama yang perlu untuk dikembangkan agar masyarakat tidak mudah terpancing dalam berbagai konflik yang bernuansa agama karena pandangan eksklusif beragama yang salah. Langkah langkah yang perlu diambil pembangunan paradigma keberagamaan dari eksklusif ke inklusif melalui sekolah, pengajaran agama seperti pengajian atau kebaktian, dan dialog antarumat beragama. Semangat inklusif ini bukan untuk mencampuradukkan ajaran agama (aqidah) yang memang tidak boleh, tetapi lebih bertujuan untuk mengikis paradigma keagamaan ekslusif yang kaku. Dengan semangat keberagamaan yang inklusif dan moderat ini diharapkan akan dapat menumbuhkan semangat kerjasama secara sosial, politis, ekonomis, dan lain-lain diantara pemeluk agama yang berbeda. Kemudian jangan terjebak hanya membangun agama sebatas pada institusi keagamaan secara fisik belaka, tetapi perlu penekanan pembangunan pemahaman keagamaan masyarakat yang inklusif dan moderat. Dengan adanya penekanan pembangunan paradigma keberagamaan masyarakat yang inklusif dan moderat, diharapkan dapat menjadi umat yang dapat saling memahami, toleran dan tidak eksklusif terhadap keberadaan umat beragama dan penganut kepercayaan lainnya. Pada titik inilah, pendidikan politik yang menekankan akan keterbukaan, saling menghargai, keadilan sangat ditekankan sebagai upaya merubah sikap dari pandangan yang bersifat eksklusifme pada sikap keberagamaan yang inklusifisme. 
Paradigma dialogis-persuasif berarti lebih mengedepankan dialog dan caracara damai dalam melihat perselisihan dan perbedaan pemahaman keagamaan daripada melakukan tindakan-tindakan fisik seperti teror, perang, dan bentukbentuk kekerasan lainnya. Paradigma kontekstual berarti menerapkan cara berpikir kritis dalam memahami teks-teks keagamaan tersebut yang membutuhkan interpretasi-interpretasi kritis dalam upaya untuk menjawab permasalahanpermasalahan keagmaan terkini. Sedangkan paradigma keagmaan yang substantif berarti lebih mementingkan dan menerapkan nilai-nilai agama daripada hanya melihat dan mengagungkan simbol-simbol keagamaan. Paradigma keagamaan aktif sosial berarti bahwa agama tidak hanya sebagai alat pemenuhan kebutuhan rohani secara pribadi saja. Hal terpenting adalah membangun kebersamaan dan solidaritas bagi seluruh manusia melalui aksi-aksi sosial yang nyata sehingga dapat meningkatkan kesejahteraan umat manusia.

\section{SIMPULAN}

Pendidikan Islam diselenggarakan dalam upaya untuk mendorong perubahan sikap atau attitude manusia dalam merespon realitas. Selain itu, pendidikan Islam sebagai landasan pendidikan politik untuk membangun tatanan masyarakat yang dialogis. Pendidikan politik pada dasarnya mensyaratkan adanya ruang demokratisasi, sebagai sarana untuk membangun masyarakat yang dialogis. Tujuan akhir pendidikan politik adalah pada perubahan prilaku serta sikap, kualitas dan berbagai aspek yang mendorong adanya ruang humanisme. Pendidikan politik hendaknya diorientasikan untuk menanamkan nilai-nilai demokratis seperti keterbukaan, perasaan saling menghargai, simpati, empati, solidaritas, dan adanya pemahaman pluralisme dalam kehidupan masyarakat Indonesia yang majemuk. Sebagai kenyataan sosial, pluralisme jika tidak dikelola secara baik akan memunculkan konflik sosial. Untuk itu dibutuhkan dialog yang merupakan jalan manusiawi untuk menyelesaikan persoalan yang muncul diantara beberapa pihak yang memiliki pandangan berbeda. 


\section{Referensi}

Abdullah, M. A. (1999). Studi Agama. Normativitas dan Historisitas. Yogyakarta: Pustaka Pelajar.

(2005). Kesadaran Multikultural. Dalam M. A. Yaqin, Pendidikan Multikultural. Cross Cultural Understanding Untuk Demokrasi dan Keadilan. Yogyakarta: Pilar Media.

(2001). Pengajaran Kalam dan Teologi dalam Era Kemajemukan di Indonesia: Sebuah Kajian Teori dan Metode. Dalam Th. Sumartana, Pluralisme, Konflik, dan Pendidikan Agama di Indonesia. Yogyakarta: Interfidei.

Al-Attas, M. N. (1984). Konsep Pendidikan dalam Islam. Suatu Rangka Pikir Pembinaan Filsafat Pendidikan Islam. Bandung: Mizan.

Aziz, A. A. (1999). Neo-Modernisme Islam di Indonesia. Gagasan Sentral Nurcholish Madjid dan Abdurrahman Wahid. Jakarta: Rineka Cipta.

Azra. A. (2012). Pendidikan Islam: Tradisi dan Modernisasi di Tengah Tantangan Milenium III. Jakarta: Kencana.

Barton, G. (1998). Gagasan Islam Liberal di Indonesia. Pemikiran Neo-Modernis Nurcholish Madjid, Djohan Effendi, Ahmad Wahib dan Abdurrahman Wahid. Jakarta: Paramadina.

Effendi, D. (1994). Konsep-Konsep Teologis. Dalam B. Munawarrahman, Kontekstualisasi Doktrin Islam Dalam Sejarah. Jakarta: Paramadina.

Esaac, F. (2000). Al-Quran Liberation and Pluraisme: Membebaskan Yang Tertindas. Bandung: Mizan.

Hidayat, K. (1994). Tiga Model Hubungan Agama dan Demokrasi. Dalam E. P. Taher, Demokratisasi Politik Budaya dan Ekonomi. Jakarta: Paramadina.

Jalal, F. (2001). Reformasi Pendidikan Dalam Konteks Otonomi Daerah. Yogyakarta: Aditia.

Kaawoan, S. (2014). Pendidikan agama Islam dalam Membentuk Perilaku Toleran pada Warga Sekolah. Jurnal Manajemen Pendidikan Islam Tadbir, 2(1).

Noer, K. A. (1998). Tuhan Yang Diciptakan dan Tuhan Yang Sebenarnya. Jurnal Paramadina, 1(2).

Noer. K. A. (2001). Pluralisme dan Pendidikan di Indonesia: Menggugat Ketidakberdayaan Sistem Pendidikan Agama. Dalam Th. Sumartana, Pluralisme, Konflik, dan Pendidikan Agama di Indonesia. Yogyakarta: Interfidei. 
Nuryatno. M. A. (2011). Islamic Education in Pluralistic Society. Al-Jamiah, Journal of Islamic Studies, 49(2).

Parekh, B. (1997). National Culture and Multiculturalism. Dalam K. Thompson (ed.), Media and Cultural Regulation. London: Sage Publications.

Rahman, F. (1980). Major Themes of The Quran. Menneapolis-Chicago: Bibliotheca Islamica.

Sulaiman, S. J. (1998). Democrazy and Shura. Dalam C. Kurzman (ed.), Liberal Islam: A Sourcebook. New York-Oxford: Oxford University.

Sumartana. (2001). Pluralisme, Konflik, dan Pendidikan Agama di Indonesia. Yogyakarta: Pustaka Pelajar.

Wahid, A. (1993). Sosialisasi Nilai-Nilai Demokrasi. Dalam M. M. Amin, \& M. Najib (ed.), Agama Demokrasi dan Transformasi Sosial. Yogyakarta: LKPSM.

------. (1989). Islam dan Masyarakat Bangsa. Jurnal Pesantren, 3(6).

(1999). Mengurai Hubungan Negara dan Demokrasi. Jakarta: Grasindo.

(1994). Agama dan Demokrasi. Dalam YB. Mangunwijaya, Spiritualitas Baru: Agama dan Aspirasi Rakyat. Yogyakarta: Dian/Interfedei.

---------. (1998). Dialog Agama dan Masalah Pendangkalan Agama, dan Kebebasan Agama dan Hegemoni Negara. Dalam K. Hidayat, \& A. Gaus AF (ed.), Passing Over Melintasi Batas Agama. Jakarta: Paramadina.

------. (1989). Kata Pengantar. Dalam E. M. Sitompul, Nahdaltul Ulama dan Pancasila. Jakarta: Sinar Harapan.

Yaqin, M. A. (2005). Pendidikan Multikultural. Cross Cultural Understanding Untuk Demokrasi dan Keadilan. Yogyakarta: Pilar Media 